\title{
Hij zag eruit als een engel
}

\author{
Sommige patiënten staan op je netvlies gebrand. \\ Nooit zal verpleegkundige Alice Tromm de hartpatiënt \\ vergeten die zij als leerling verpleegde: \\ een jongeman met anorexia.
}

tekst Alice Tromm illustratie Stouthandel

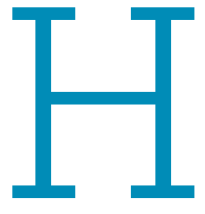
et was 1976 De laatste drie maanden van de verpleegkunde A-opleiding werkte ik op de afdeling ccu van het Wilhelmina Ziekenhuis (nu AMC Amsterdam) bij professor Van Düren. Het was een geweldig team, met een schat van een hoofdzuster. De meeste patiënten waren mannen van middelbare leeftijd. Vaak gingen zij na twee tot vier dagen naar een gewone afdeling. Het verloop was vrij groot. Een enkele keer bleef iemand langer als hij moest wachten op een interne pacemaker. Sommigen overleden na een massaal hartinfarct, maar als leerling had ik al veel overlijdens meegemaakt en ik kon het een plaats geven.

\section{Hartslag}

Die dag kwam ik met late dienst op de afdeling, waar een jongeman van 25 jaar was opgenomen met hartproblemen. Hij had extreme anorexia, wat voor $95 \%$ alleen bij jonge meisjes en vrouwen voorkomt. Het was

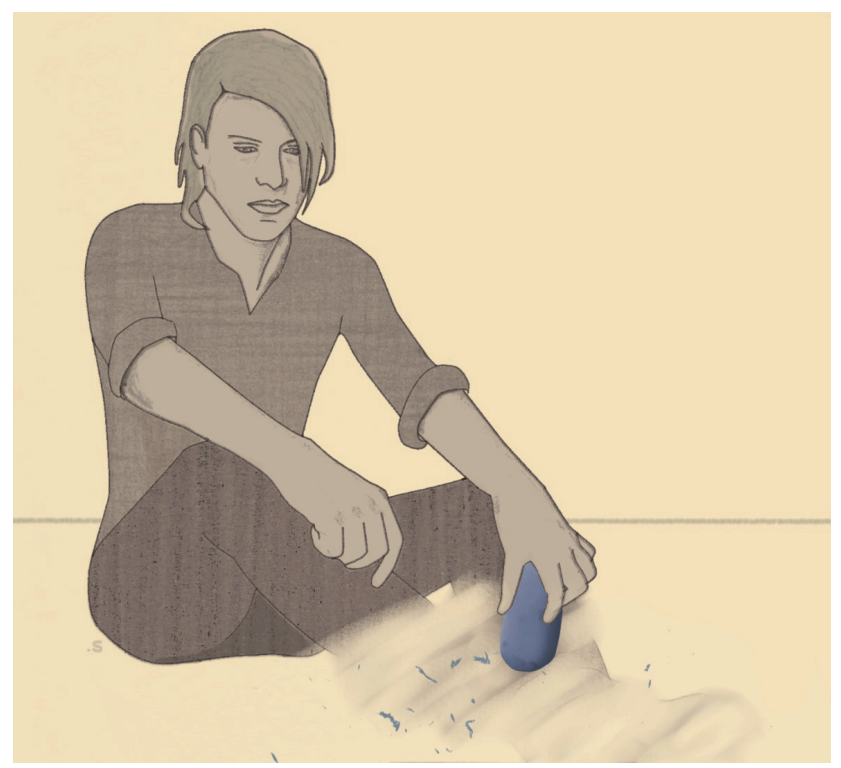

een heel lange man met halflang blond haar en helblauwe ogen. $\mathrm{Zijn}$ vingers waren lang en mager en hij had een doorzichtige uitstraling. Hij zag eruit als een soort engel en had een extreem hoge hartslag van over de 200 per minuut.

Ik kreeg de opdracht om heel langzaam $10 \mathrm{cc}$ bèta-

\section{Na mijn dienst fietste ik huilend naar huis}

\section{Schuldig}

Ik gooide de spuit op tafel en legde het hoofdeinde plat, klaar voor reanimatie. Ondertussen renden mijn collega's naar binnen en namen het over, terwijl ik met tranen in mijn ogen stond toe te kijken. Hij haalde het niet en ik voelde me schuldig. $\mathrm{Zij}$ vertelden mij dat deze man als gevolg van zijn ziekte ook laxeermiddelen gebruikte en overtuigden mij dat zijn dood niet mijn schuld was. Maar na mijn dienst fietste ik huilend naar huis. Ik belde een vriend die langs kwam om te troosten. Opvang was er niet. Zo ging dat toen: get over it, je bent verpleegkundige, je bent sterk. Je hebt het meer meegemaakt.

Waarom ben ik deze patiënt nooit vergeten? Ik was zelf net 27 , stond aan het begin van mijn leven en kon niet accepteren dat iemand van 25 overleed. Eigenlijk was het een langzame zelfmoord. Ik heb hem maar twintig minuten gezien en geen woord gewisseld. Maar ik kan zijn gezicht zo uittekenen. Waarom? Ik weet het niet. 